Dialectic Volume I, Issue I: Visual Essay

\title{
My Life as a Fake
}

JENNY GRIGG ${ }^{1}$

1. Royal Melbourne Institute of Technology (RMIT) University, Melbourne, Australia

SUGGESTED CITATION: Grigg, J. “My Life as a Fake.” Dialectic, 1.1 (2016): pgs. 111-134. DOI: http://dx.doi.org/10.3998/

dialectic.14932326.0001.108 



\section{My Life as a Fake}

JENNY GRIGG

\section{Introduction}

The array of design work presented on the following pages is comprised of a set of images I created as part of my professional practice between 2003 and 2006. They emerged as I engaged in the process of designing covers for novels written by the contemporary Australian author Peter Carey.

Often considered merely catalytic to what will emerge as the final outcome of the design process, graphic explorations such as these are often discarded. However, when they are preserved and intentionally displayed, they constitute a visual and ontological representation of the ideas that occur during the design process and inform its progression. ${ }^{1}$ Reflection on these various test pieces guided a form of analysis, "a designerly way of knowing," ${ }^{2}$ that allowed me to examine how materially-led explorations with paper could enable the translation of abstract design concepts into visual forms.

Goldschmidt, G. (2003). "The Backtalk of Self-Generated Sketches." Design Issues, 19(1), 72-88; and Schön, D. A. (1983). The reflective practitioner : how professionals think in action. Aldershot: Avebury. doi:10.1162/07479360376266772

Cross, N. (2007). Designerly ways of knowing. Basel: London: Birkhäuser; Springer distributor.
The first half of this visual narrative depicts the design process that guided the development of the cover designs for the first Australian edition of Peter Carey's novel My Life as a Fake on behalf of Random House in 2003. The second half recounts my engagement in the design process that resulted in a more recent-2006 - version of the cover design for the same novel, but this latter version was designed for Random House as an integral part of a series of nine covers for books authored by Peter Carey.

This visual narrative is an example of asserting the idea of transmediation, (transfer to a different medium), within the context of a specific graphic 
design project. By intentionally changing the materials with which I was designing, I employed a strategy to promote ideatic renewal (Stamm, 2013). ${ }^{3}$ As described in a 2007 article by Aaron Seymour that was published in 'Eye Magazine' about my design work for the covers of Carey's books, this intentional paradigm shift enabled me to "Do it again (Seymour, 2007)." 4

\section{My Life as a Fake, 2003}

The plot of the novel is centered on a series of actions set in motion in the mid 2oth century by a frustrated poet named Christopher Chubb, who perpetrates a literary hoax in Australia by creating poetry authored by a fictitious, working class Australian poet named Bob McCorkle. Chubb creates McCorkle and his work to demean and disrupt modernist poetic doctrine and to humiliate an editor who has rejected his work, and who Chubb regards as pompous. The poetry Chubb writes under McCorkle's name is compiled into a manuscript that, as the plot of the book progresses, becomes symbolic of the dubiousness and false pretention that pervades many of the characters and the world they inhabit. Eventually, amidst all of the posing and fakery, a man emerges who successfully and monstrously passes himself off as Bob McCorkle, and becomes the only character in the book who emerges as genuine.

When I first received the manuscript for My Life as a Fake, it came to me on approximately 250 sheets of A4-sized, 8ogsm (grams per square meter) Bond typing paper. This is a ubiquitous tool in publishing in Australia, New Zealand and much of western Europe. Being cheap, available and conceptually relevant-Chubb typed the fictitious McCorkle's poetry on the same type of paper-I decided to experiment with white pages of Bond during my design process, and much of it involved my investigation of its physical properties and image-making potential.

Viewed as a sequence, the images signify depictions of the choices I made that guided the direction of the design for this piece and that also offer visual evidence of Schön's theory of "refection-in-action." 5

Displayed more or less chronologically, the narrative begins with sketches (depicted in Figures 1 through 4 ) that recorded my thoughts ${ }^{6}$ during my initial study of Carey's manuscript. Recording the iterative progression from literal to abstract concepts, the sketches reflect my intention to achieve an experimental result. For example, Chubb is initially rendered as a person with arms, legs and a face (as shown in Figures 1 and 2), and later, in order to express characteristics that are temperamental rather than physical, Chubb is 
Goldschmidt, G. (2003). "The Backtalk of Self-Generated Sketches." Design Issues, 19(1), 72-88; and Schön, D. A. (1983). The reflective practitioner : how professionals think in action. Aldershot: Avebury. doi:10.1162/07479360376266772

8

Cross, N. (2007). Designerly ways of knowing. Basel: London: Birkhäuser; Springer distributor.

Viray, E. (2011). Why Material Design? (Vol. Material Design, Informing Architecture by Materiality, pp. 8-10). Switzerland: Birkhåuser GmbH .

10

Cross, N. (2007). Designerly ways of knowing. Basel: London: Birkhäuser; Springer distributor. realized as a smudge (as shown in Figure 3), and also as two characters to portray his schizoid nature (as shown in Figure 4).

Sketching my thoughts about various means to visually communicate the book's essential themes onto paper gave them visible presence, and made them physically tangible enough for me to manipulate and hybridize more easily. This aided my conceptual development process by providing evidence that could facilitate the process of critical appraisal. ${ }^{7}$ Inspired by Carey's reference to "sparagmos,"a concept from Greek mythology that implies dismemberment, or tearing things apart, the later sketches are attempts to encode this concept visually ${ }^{8}$ by allowing the composition to be dominated by an apparently haphazard arrangement of pieces of Bond paper (as shown in Figures 5-7). The pages appear to be thrown up and are being dismembered in mid-air.

Additional reflection on these sketches enabled me to realize that these falling pages could be encoded on a further level and composed to simulate ${ }^{9}$ a despairing author's face (as shown in Figure 6). Satisfied that this concept was inherent to both the fictional themes being explored in Carey's narrative as well as in the material - the Bond paper - being tested, the second half of the narrative illustrates a transmediation process, from sketching to material testing (as shown in Figures 8-16).

These images demonstrate how haptic experiments (in this case, literally involving material handling) facilitated the creation of an abstraction of a face that I created from pieces of backlit Bond paper. Figure 8 depicts one of my tests that involved overlapping pieces of Bond paper to render this illusion. This type of test is an example of materially-driven visual encoding. ${ }^{10}$ One piece placed horizontally at the top of the composition signifies the forehead, two splayed pieces placed in the midst of the composition signify the cheeks, and one piece placed below these implies a chin or a neck. The areas of overlap contribute two eyes, a nose and a mouth. The fact that none of the pieces is arranged in "perfect" vertical or horizontal alignment helps to visually communicate that the persona being rendered is anything but a well-adjusted citizen of a modernist society.

Subsequent experiments proved the paper's ability to hold a curl and cast a shadow when lit by a single source of light (as shown in Figures 1012). These images demonstrate how particular placements of these curls within the abstract rendition of a facial structure could be used to encode various expressions. 
11

Tyler, A. C. (1992). Shaping belief: The role of audience in visual communication (Vol. Design Issues 9, pp. 21-29).
Given its recognizable structure and long history of being abstracted in a variety of materials and across a diverse array of mediums, I surmised the face in these designs would be decoded quite easily by the intended audience ${ }^{11}$ for this piece. I also surmised that this audience would be less apt to decode the reference to a literary manuscript typed on Bond paper, although I didn't consider this necessary to the success of the design. As this design is unpublished as of this writing, these predictions remain untested.

Typographic tests (as shown in Figures 11 and 12) provided an alternate design direction to my idea of arranging pieces of Bond paper to create the perception of faces. Starting with graphic representations of a spare, empty page, (as shown in Figures 14 and 15), I trialed overlaid placements of pieces of paper containing portions of letterforms and noticed that since they were the same color as the background, this gave the effect of corroding the page edges and fracturing the surface of the design (as shown in Figure 16). Decoding these material behaviors as I designed, I made an intellectual connection between the appearance of this fragmentation, the creative challenge of writing, and "sparagmos." Considering the sophistication of Carey's prose, this less figurative, more abstract option depicted in Figure 16 was the one proposed to the publisher. 

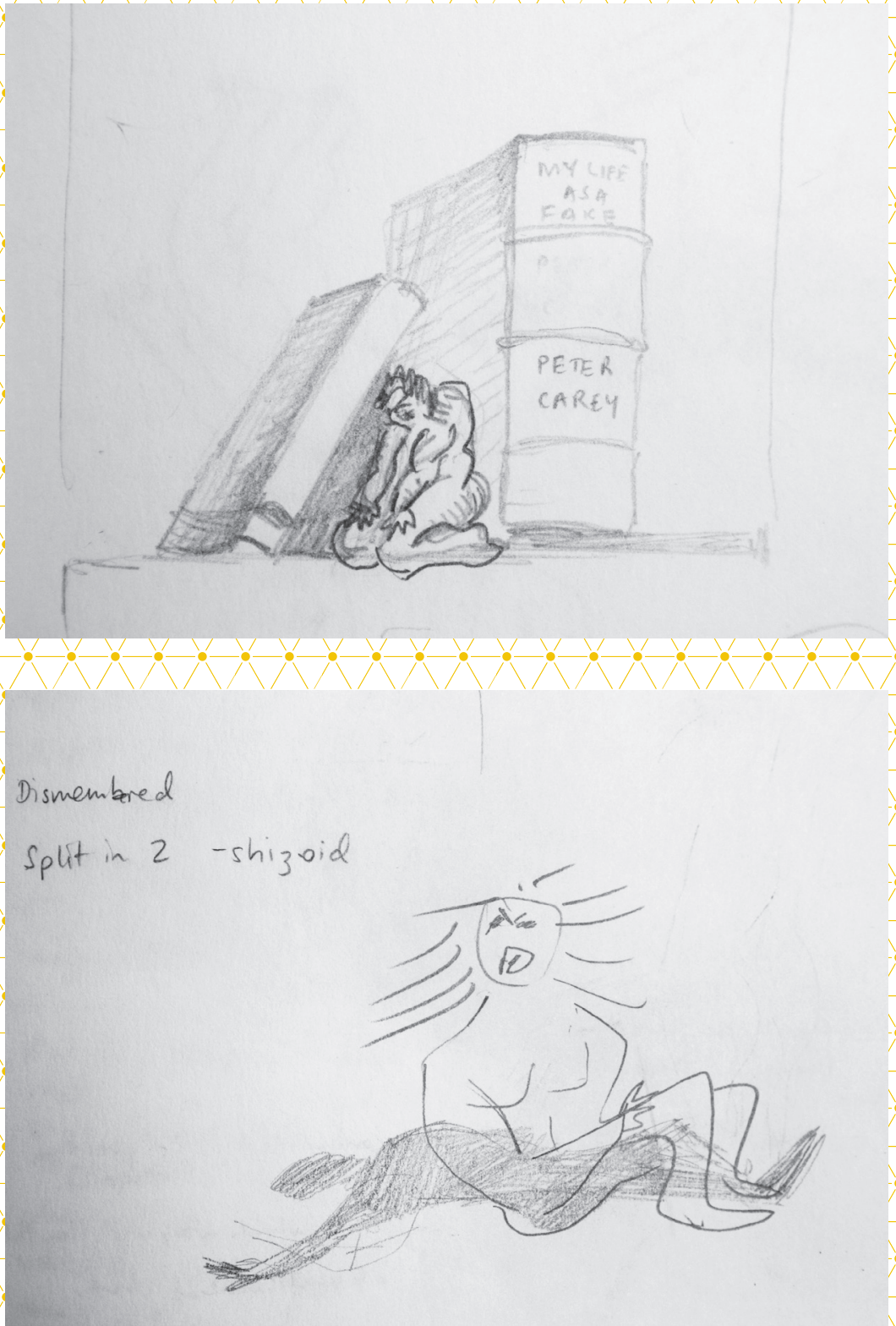

ABOVE: My Life as a Fake (2003) Figures 1-2. 

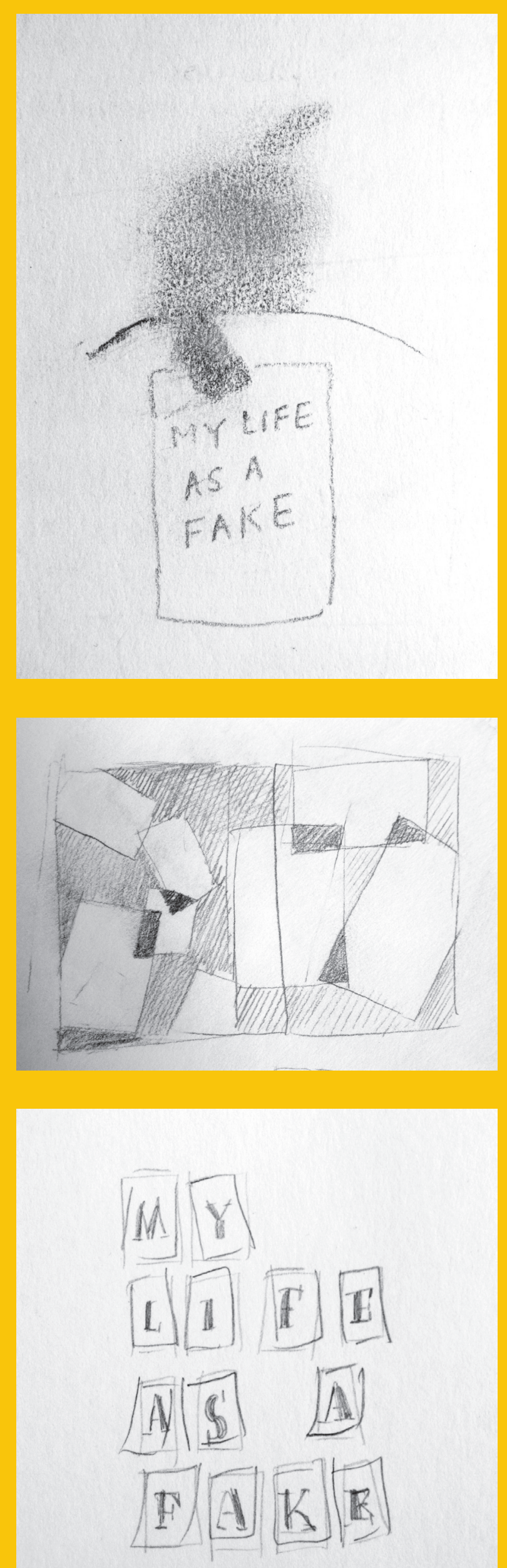

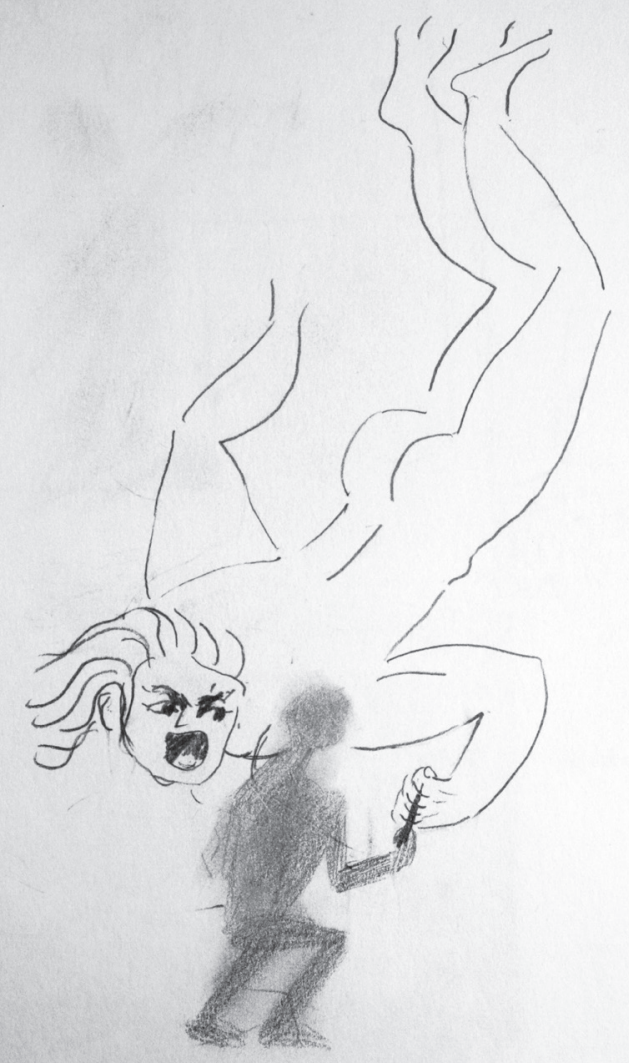

CLOCKWISE: My Life as a Fake (2003) Figures 3-7.

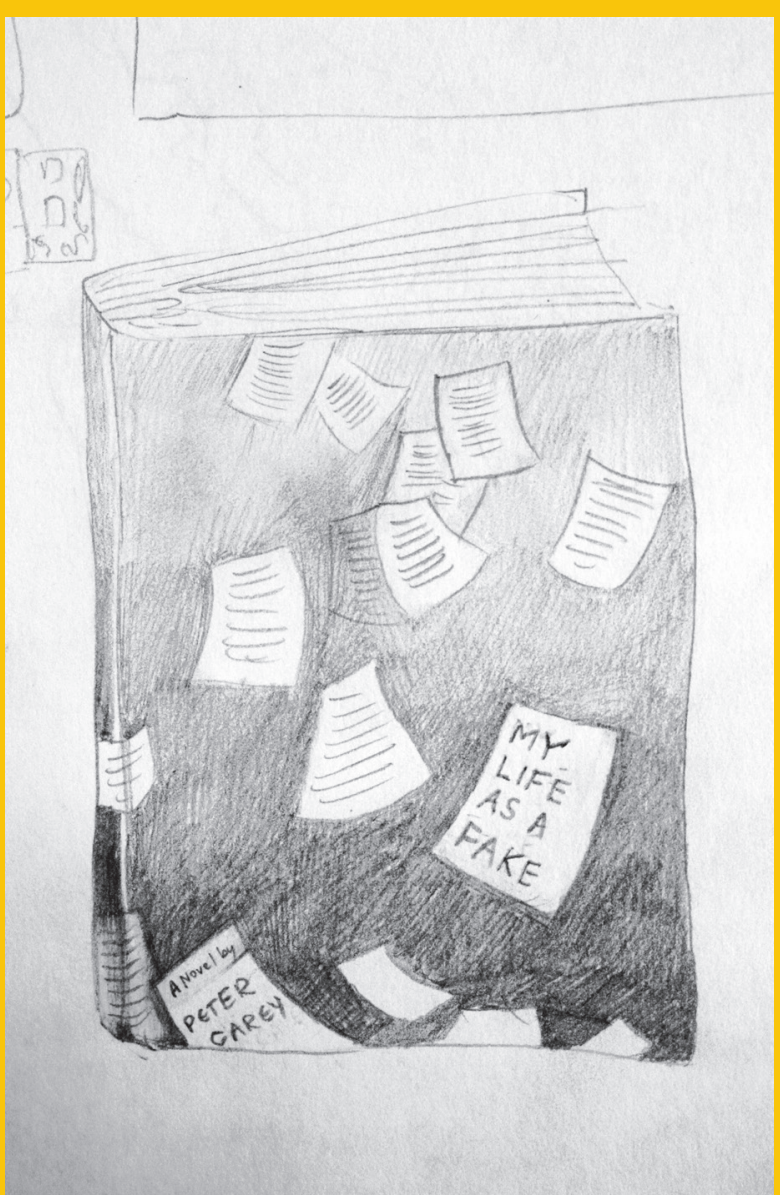




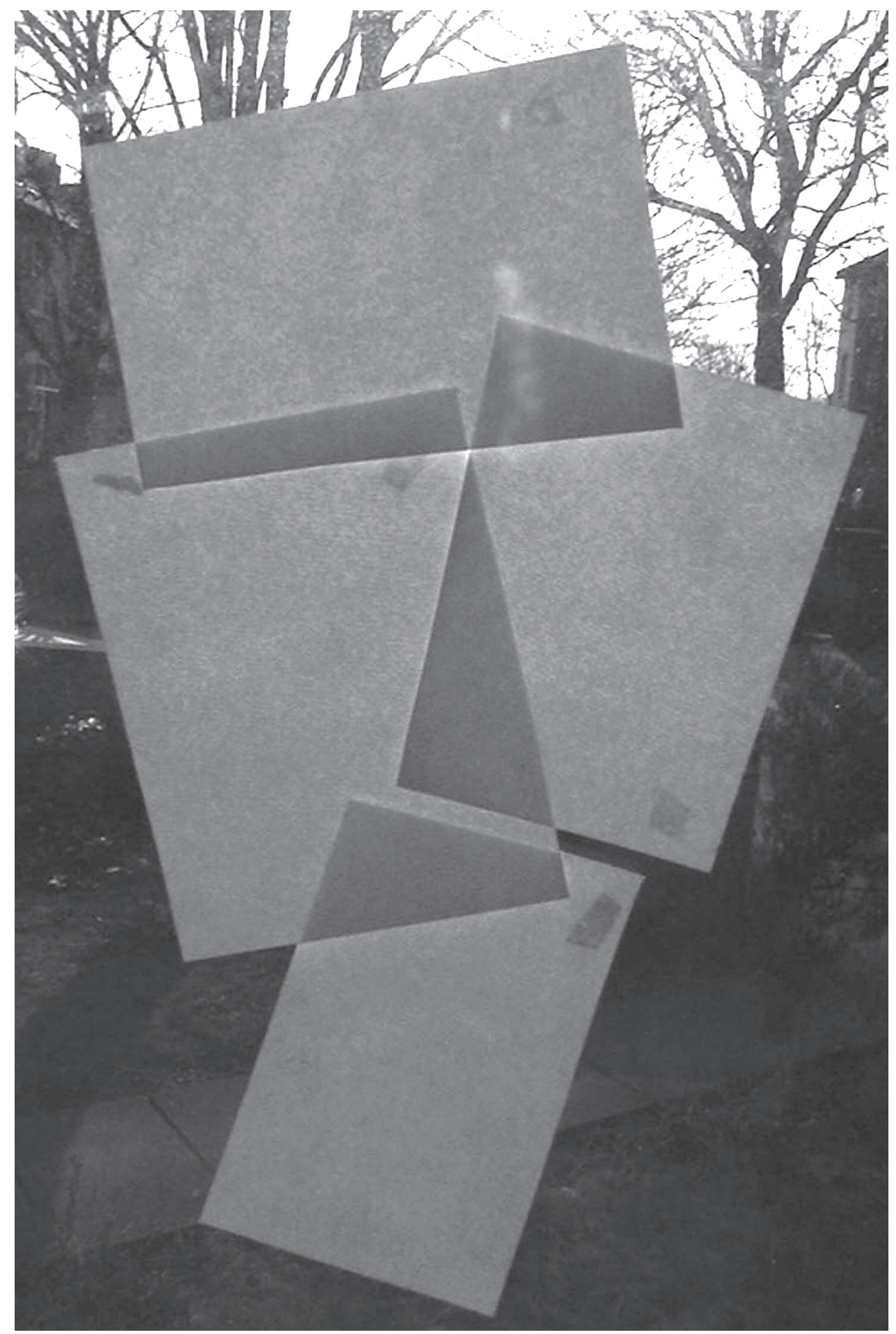




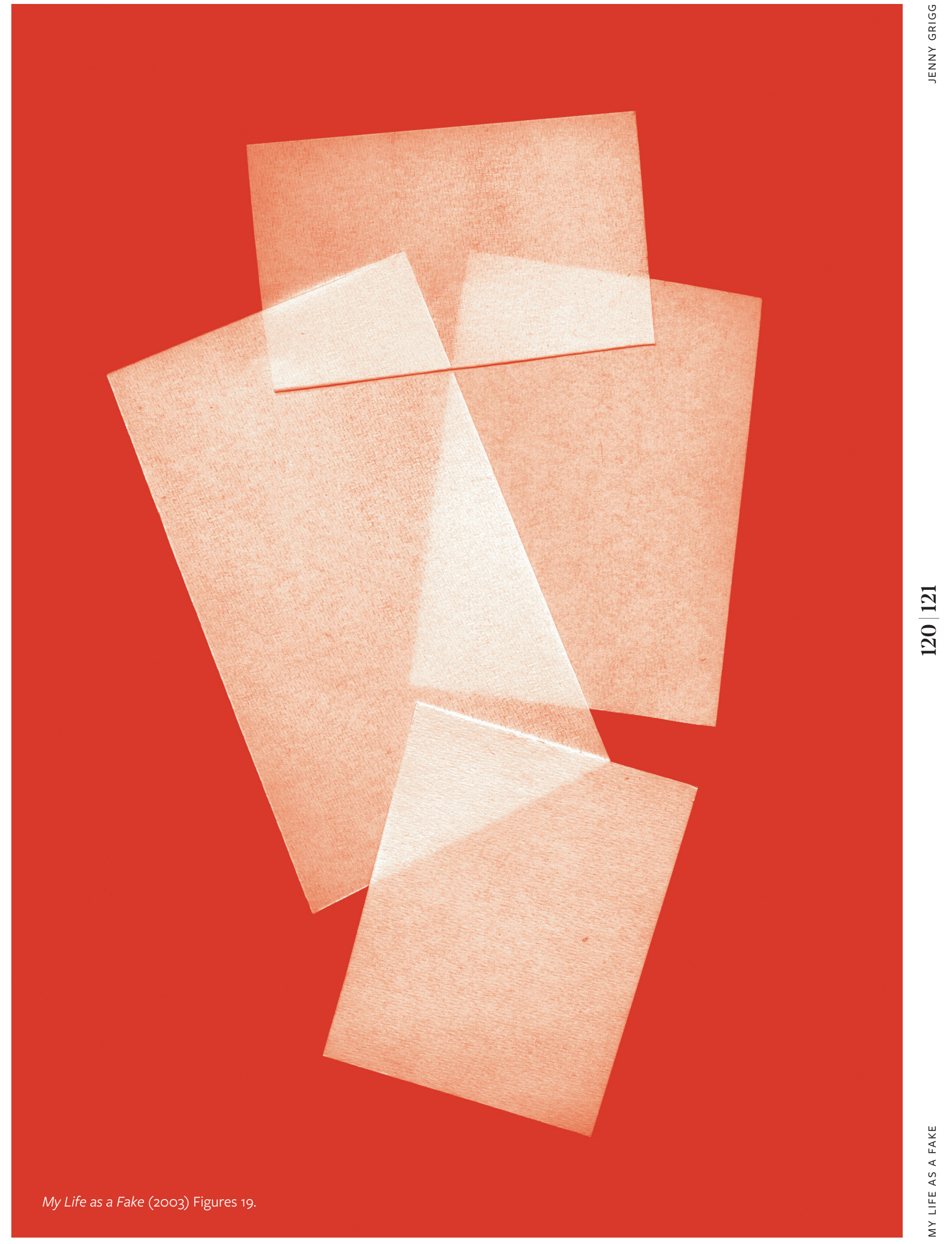



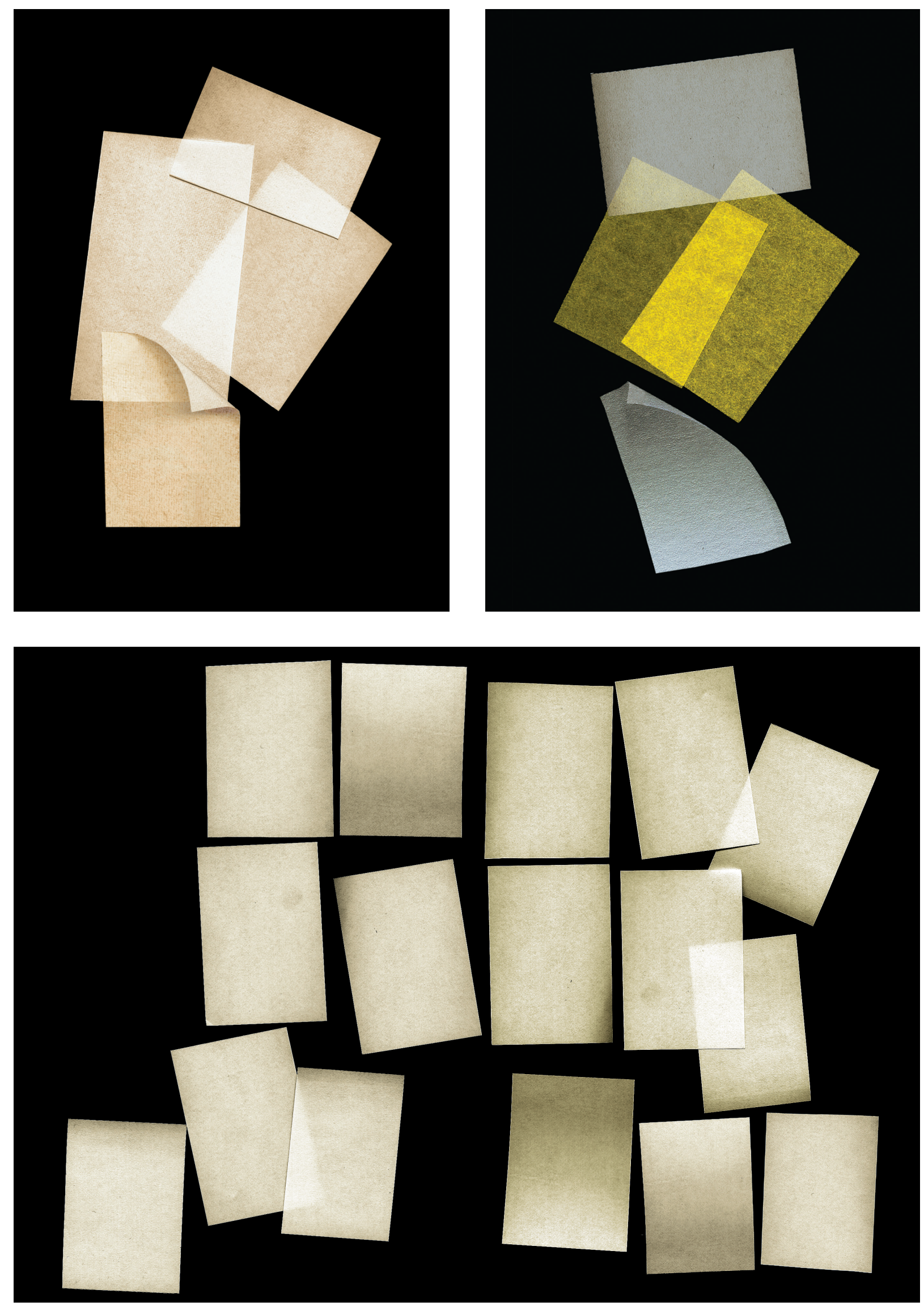

CLOCKWISE: My Life as a Fake (2003) Figures 10-12. 

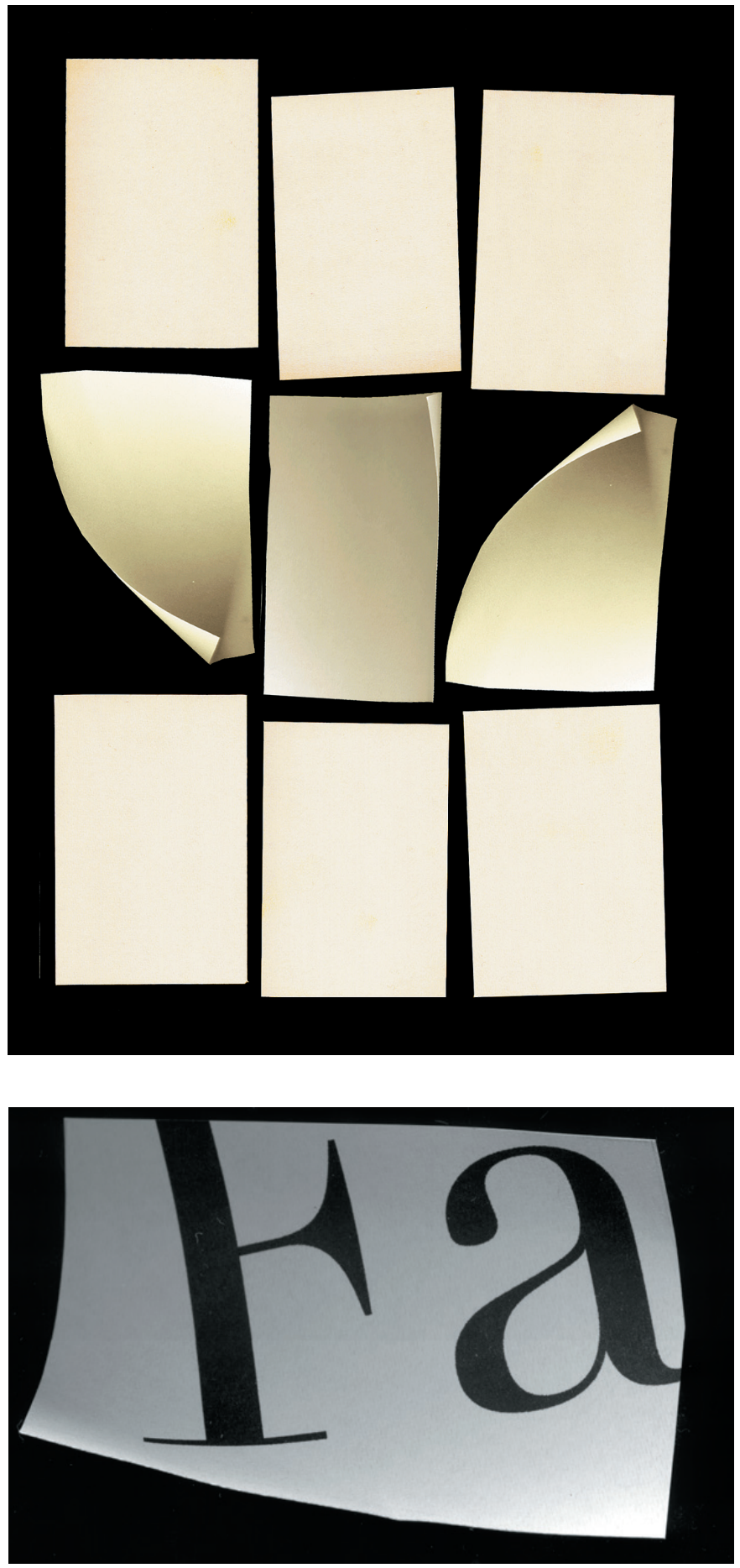

$\frac{\dddot{3}}{\bar{บ}}$

TOP то вотто м: My Life as a Fake (2003) Figures 13-15. 


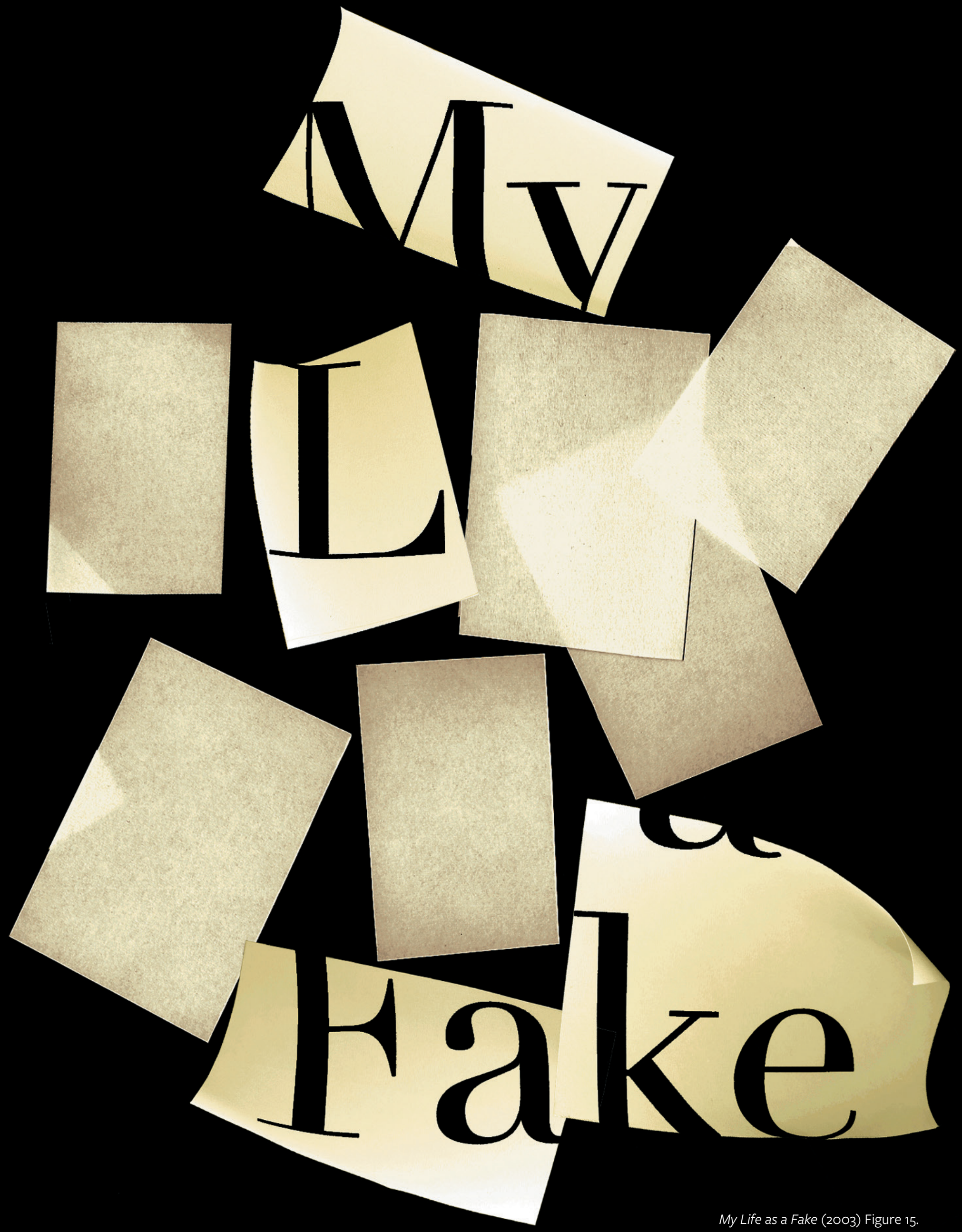




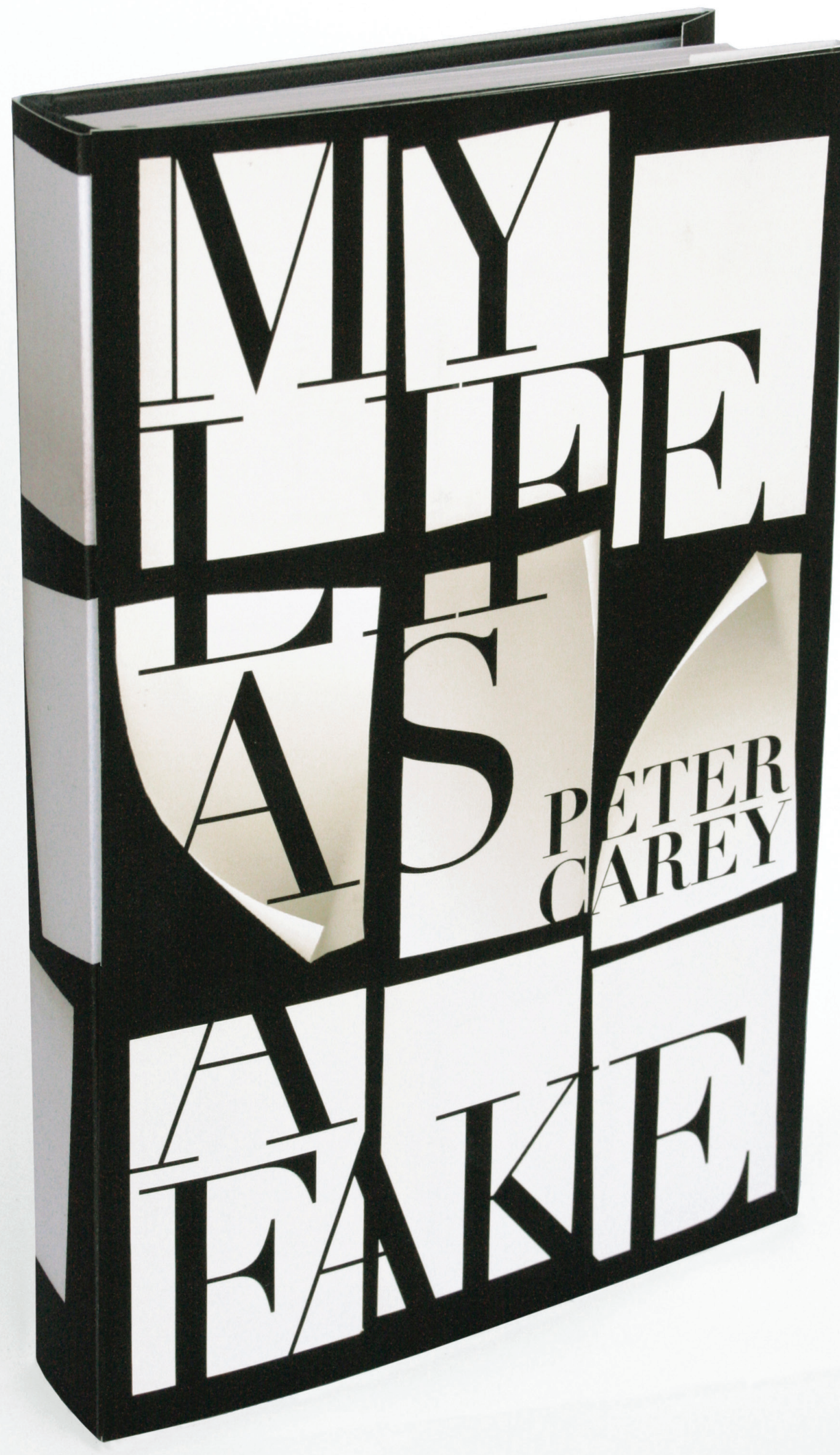

ABOVE: My Life as a Fake (2003) Figure 16. 


\section{My Life as a Fake, 2006}

The client for this piece (Random House) required me to produce multiple, visually related design options, so I opted to construct a visual language of formally congruent shapes, textures and spaces, also known as a "relational (design) system," ${ }^{12}$ from which nine, visually cohesive translations could be made. To do this, I revisited some unexplored results of tissue paper tests I had made in 2003 (as shown in Figure 17). The second array of design work described in this piece recounts aspects of the "operational testing" 13 that were undertaken to create this particular visual language. It includes evidence of which compositions were created and assessed, what the results of this process were, and, ultimately, how these were implemented.

The evolution of this concept was guided by my interest in constructing knowledge derived from examining the materiality of specific substancesin this case, tissue paper and other translucent materials - in this revisitation of the cover design for My Life as a Fake, as well as for a few other of Carey's more significant books. The results of this type of materialistic examination informing and guiding design processes are evident across the history of many design disciplines. Alvar Aalto sometimes featured burnt and mis-shapen bricks in buildings he designed, ${ }^{14}$ fashion designers routinely craft garments based largely on their responses to the material qualities of specific types of fabric, plastics and sheeting, and graphic designers going back to Paul Rand, Saul Bass, Bradbury Thompson and several Russian Constructivists have experimented with allowing materialistic approaches like the simple overprinting of translucent areas of color inform their design processes. Printing a portion of a yellow area over a portion of a red area creates an orange area where they intersect, and can also create an opportunity to allow that area to signify a specific message.

As a sort of graphic design game, I often find myself mentally decon-

Gursoy, B. (2015). Visualizing making: Shapes, materials, and actions. (Report). 41, 29. doi:10.1016/ j.destud.2015.08.007

13

Downton, P. (2003). Design research. Melbourne: RMIT Publishing.

14.

Sennett, R. (2008). The craftsman. New Haven \& London: Yale Universtiy Press. structing graphic design compositions to try and decipher their technological and metaphoric make-up. A critical examination of a tissue-paper kite design by Ray and Charles Eames provided the inspiration for using overlaid areas of tissue paper to convey various effects of the interactions between some of the principal characters in My Life as a Fake.

To develop a set of test compositions that would allow me to experiment with different ways of doing this that effectively conveyed an essential theme from a given book, I progressively cut and arranged figurative shapes in various paper colors (as shown in Figures 18-26). As I engaged in this process, 
15

Gursoy, B. (2015). Visualizing making: Shapes, materials, and actions.

(Report). 41, 29. doi:10.1016/ j.destud.2015.08.007; and Viray, E. (2011). Why Material Design? (Vol. Material Design, Informing Architecture by Materiality, pp. 8-10). Switzerland: Birkhåuser $\mathrm{GmbH}$.

16

Walwin, J., \& Krokatsis, H. (2006). You'll never know : drawing and random interference. London: Hayward Gallery.
I realized that overlaying transparent, shaped areas of color in these compositions could effectively signify particular ideas, or the personality traits of specific characters, or significant moments in a plot. For example, by placing a depiction of the outlaw character Ned Kelly's armored mask in orange over his black profile (as shown in Figure 20), we perceive both of Kelly's personas - a feared and "wanted" lawbreaker and a tragic human figure-simultaneously. This treatment of this legendary character from the fringes of Australia's rugged 19th century helps visually communicate Carey's choice to render the tale from a first-person perspective. I employed a similar tactic to signify the intimacy that slowly-but-surely evolves between the main characters of Carey's eccentrically rendered love story Oscar and Lucinda. In this composition, I placed a shape depicting Oscar underneath that of one depicting Lucinda, and designed his arms to be brought forward and literally fold around her waist. Manipulating their tissue paper shapes further, I learnt that if I brought his head forward of Lucinda's, their two forms became further entwined, merging their faces and increasing the perception of a disparate two becoming a cohesive one.

These experiments with over-lapping shapes of colored paper revealed ways to coax particular expressions of meaning from given images by concurrently exploiting the inherent transparency and pliancy of the material. ${ }^{15}$ It also became apparent that it was necessary to combine colors that contrasted clearly to achieve graphic clarity. Because of its density and low value, black provided an effective background contrast when used as the base layer in a composition, and it was formally powerful enough to be perceived through two additional overlays (as shown in Figure 24). I proceeded to prioritize the use of a black component within the composition of each design.

Figure 26 depicts the version of this round of experimentation that was eventually published. It is the result of me using knowledge gleaned from engaging in a materialistic examination of overlaid tissue paper to inform my design decision-making. In this composition, Chubb is represented as a diminished figure crudely cut from blue tissue paper, at once embracing and being devoured by the towering, black menace of his creative aspiration. The "overprint effect" was achieved by manipulating the intersection of the blue and black shapes and this placement led to the chance creation of a gestalt-based form. Positioned underneath the blue layer, the black shape emerged to depict both Chubb's schizoid alter ego and a shadow cast by the Chubb sensu. ${ }^{16}$ 
The understandings I gained as I engaged in these materialistically informed design processes led me to the simple revelation that examining the material properties of given substances as an essential part of my working process could yield conceptually well-founded and aesthetically compelling results.

BELOW: My Life as a Fake (2006) Figures 17.

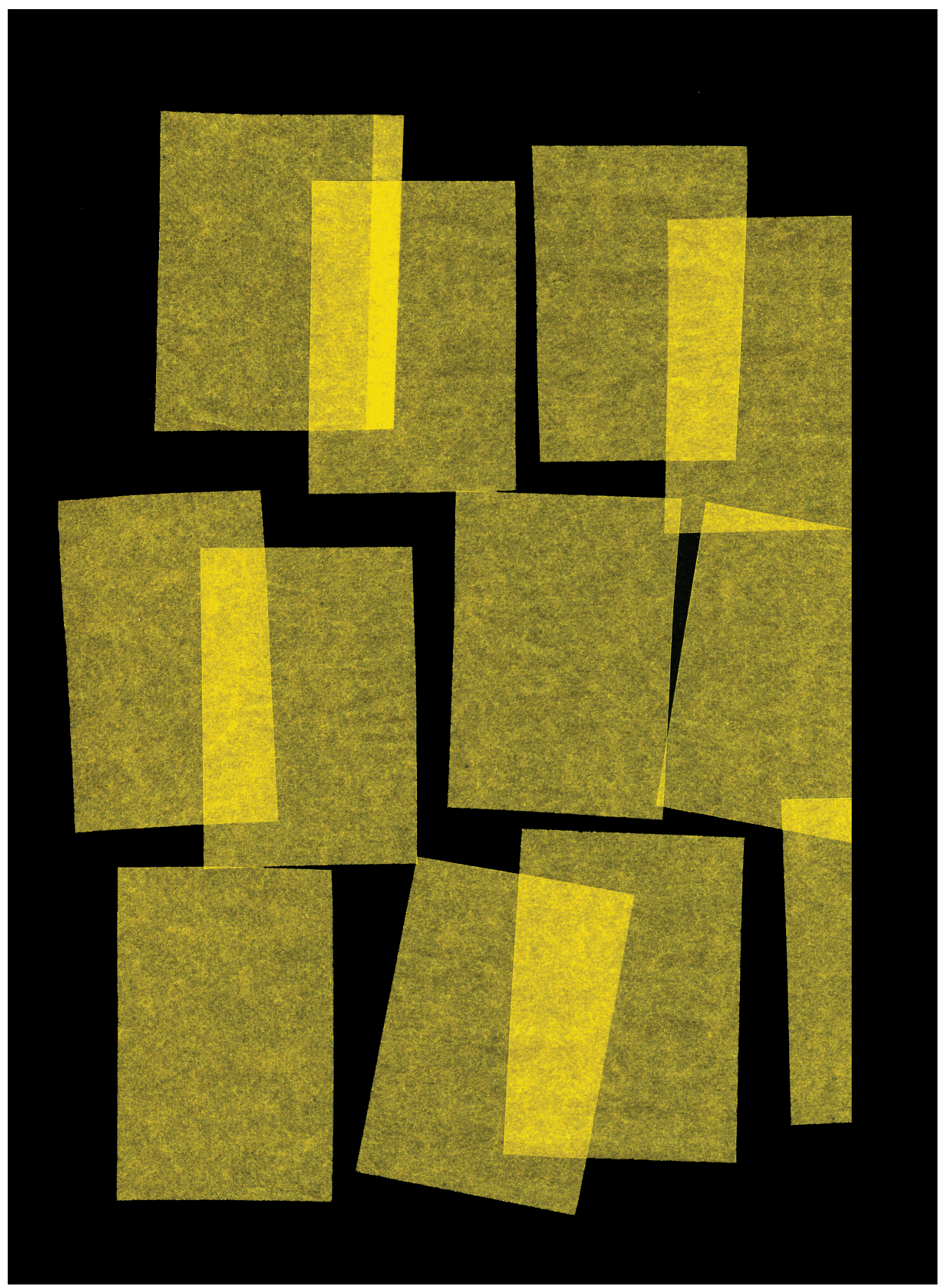



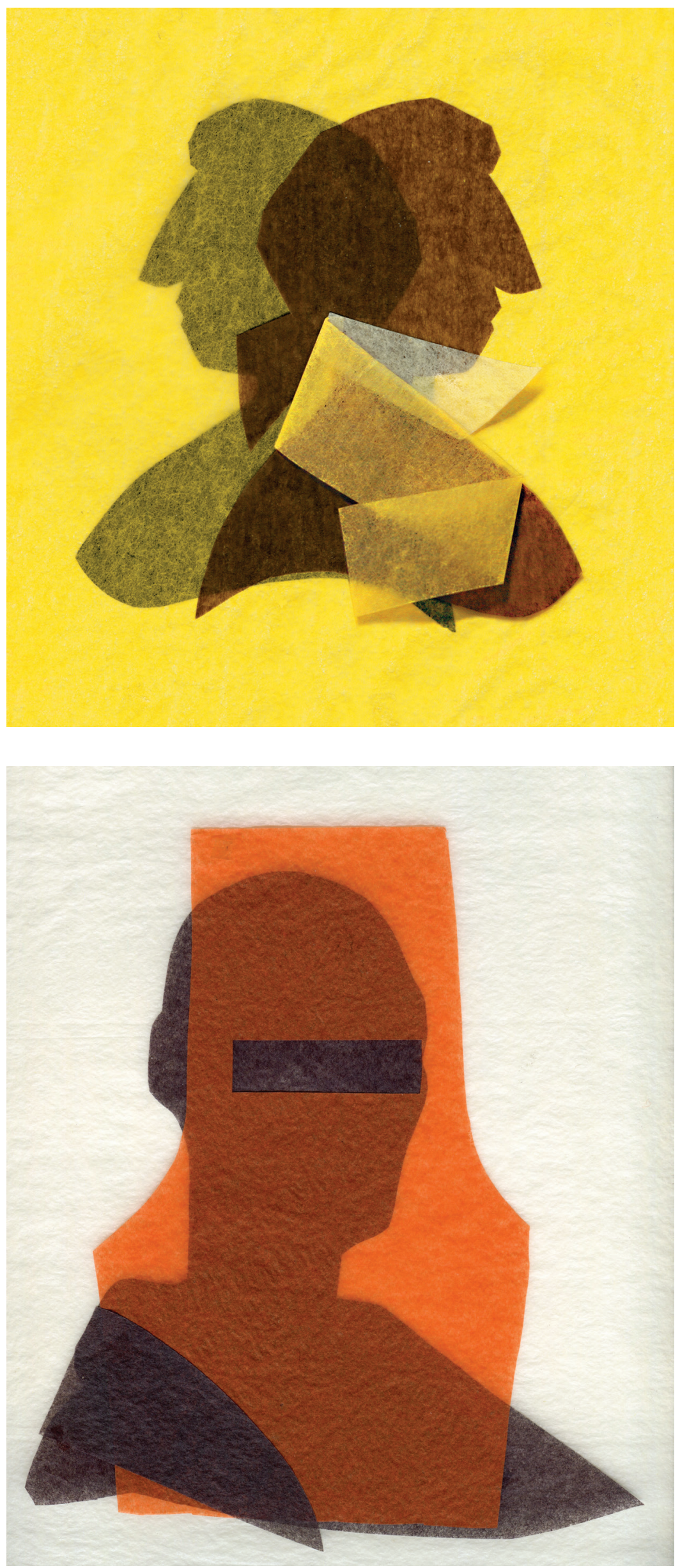

$\frac{\mathscr{3}}{\stackrel{3}{\mathfrak{I}}}$ 

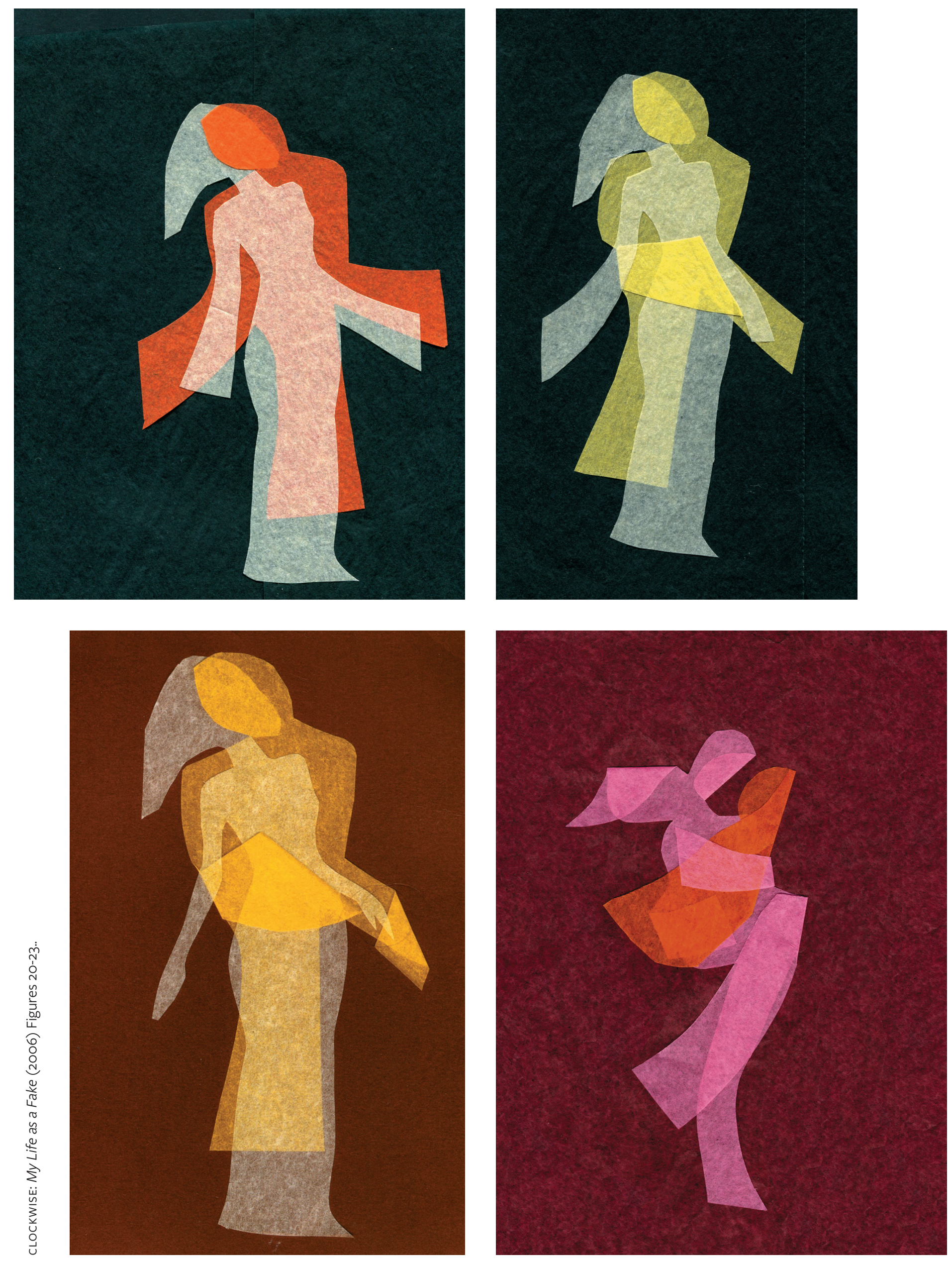


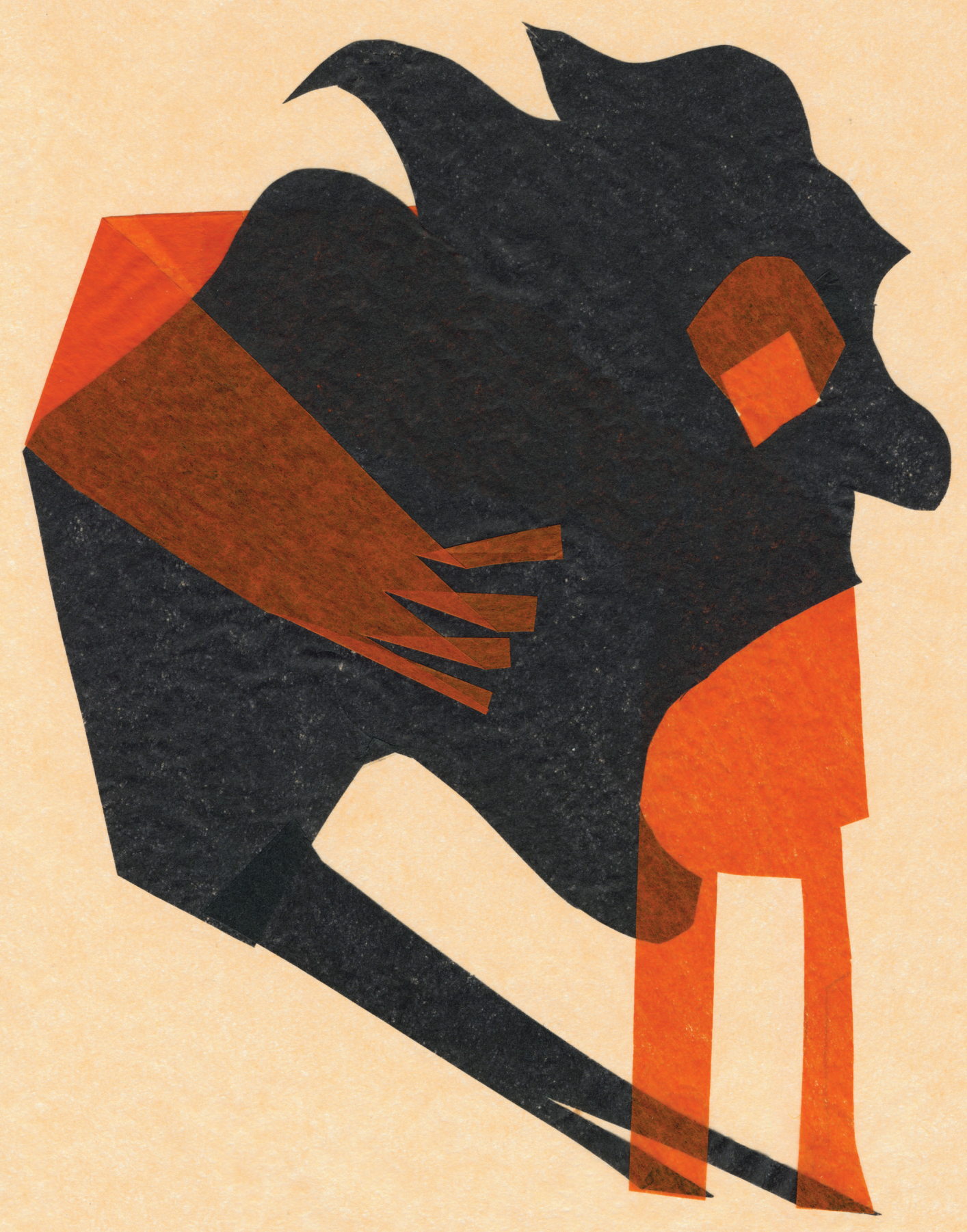

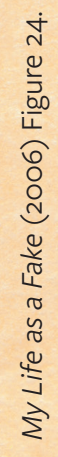


peter carey 


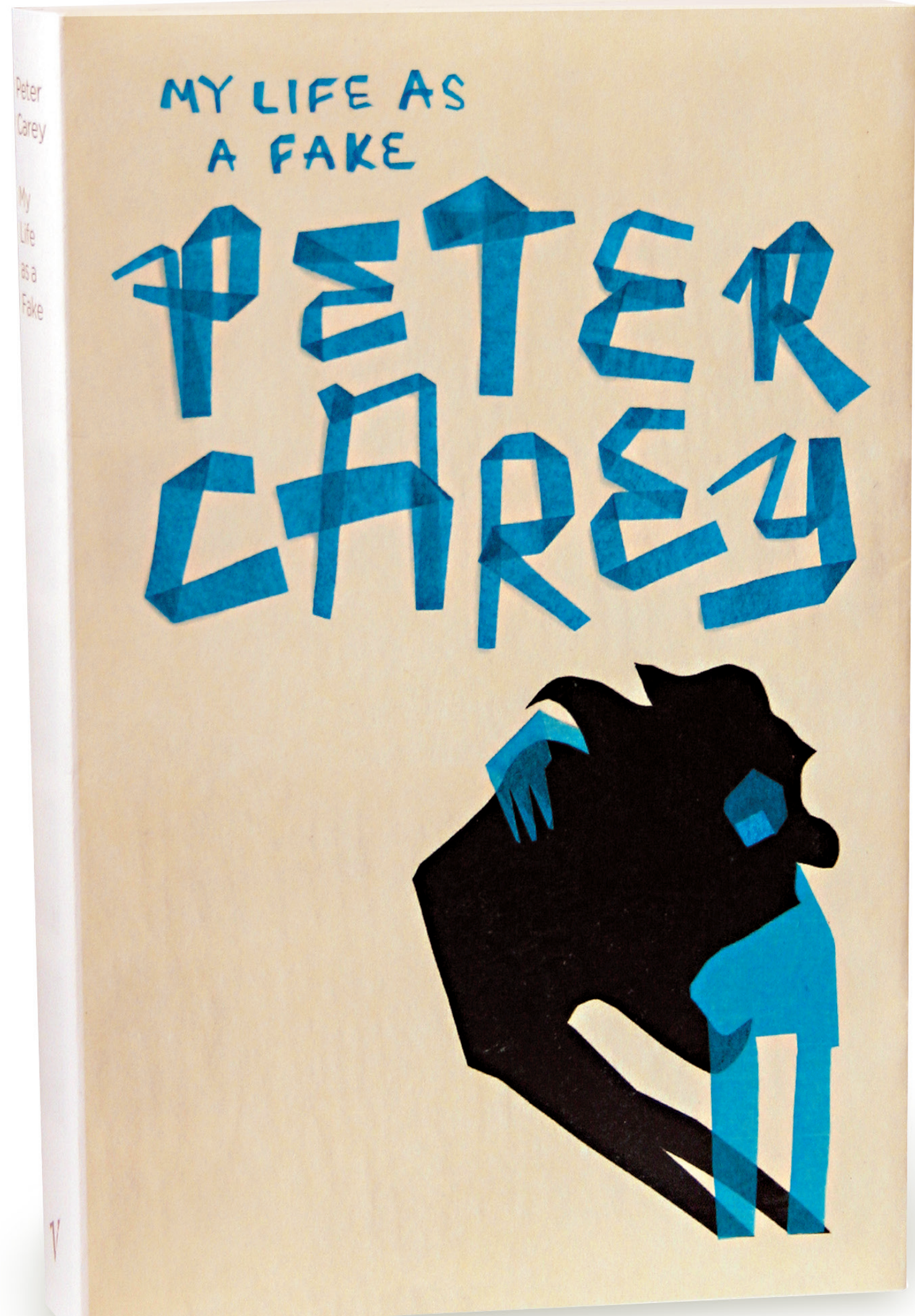




\section{References}

Cross, N. (2007). Designerly ways of knowing. Basel : London: Birkhäuser ; Springer distributor.

Downton, P. (2003). Design research. Melbourne: RMIT Publishing.

Goldschmidt, G. (2003). “The Backtalk of Self-Generated Sketches.” Design Issues, 19(1), 72-88. doi:10.1162/074793603762667728

Gursoy, B. (2015). Visualizing making: Shapes, materials, and actions.(Report). 41, 29. doi:10.1016/j.destud.2015.08.007

Schön, D. A. (1983). The reflective practitioner : how professionals think in action. Aldershot: Avebury.

Sennett, R. (2008). The craftsman. New Haven \& London: Yale Universtiy Press. Seymour, A. (2007). "Do it Again.” Eye Magazine, 17(65).

Stamm, M. (2013). Reflecting reflection(s)-Epistemologies of Creativity in Creative Practice Research. In J. V. a. B. Pak (Ed.): LUCA, Sint-Lucas School of Architecture (Ghent, Belgium).

Tyler, A. C. (1992). "Shaping belief: The role of audience in visual communication” (Vol. Design Issues 9, pp. 21-29).

Viray, E. (2011). Why Material Design? (Vol. Material Design, Informing Architecture by Materiality, pp. 8-10). Switzerland: Birkhåuser GmbH.

Walwin, J., \& Krokatsis, H. (2006). You'll never know : drawing and random interference. London: Hayward Gallery.

\section{Biography}

Jenny Grigg is an Australian graphic designer, a lecturer in visual communication at Monash University in Melbourne, Australia, and a Ph.D. candidate at the Royal Melbourne Institute of Technology (RMIT) University. Since graduating from the University of Technology in Sydney, Australia, Jenny has held several professional graphic design positions. These include stints as Art Director at Rolling Stone Magazine Australia, Art Director at HQ Magazine and MTV Australia. After a year in London designing for Pentagram and Faber \& Faber, she became the Creative Director for Harper Collins Publishing in Sydney. Jenny continues to operate her design practice and is an Industry Fellow at RMIT University. 
DIALECTIC: VOLUME I, ISSUE I

Designing graphic materials to support and promote the work of authors such as Peter Carey-Australia's best-known contemporary novelistand on behalf of clients such as Granta Portobello Books in London, her creative inception begins with a deeply probative analysis of a given author's written words. As a Ph.D. candidate, she has begun to make use of the variety of epistemological understandings she has been able to cultivate by doing this.

She is currently conducting collective case study research about various forms of graphic design ideation (the formulation of ideas). Specifically, she is researching how professionals use materialistic approaches to guide regenerative, creative processes in graphic design practice. 